\title{
WORKER OPPOSITION IN THE RUSSIAN JEWISH SOCIALIST MOVEMENT, FROM THE I890's TO $1903^{1}$
}

The emergence of nineteenth century socialism as a mass political movement required the cooperation of two distinct elements - a radical intelligentsia, and a working class whose interests the former purported to represent. In theory these two elements were to fuse into a harmonious whole, but in fact certain tensions arose, whether between trade union and party or between workers and intellectuals within the same organization. ${ }^{2}$ It is my intention to consider this problem within the context of the Russian Jewish socialist movement. Specifically, this entails an examination of the various forms of worker opposition to the leadership of the socialist "circles" of the I880's and I 890 's and to the leadership of the "General Jewish Labor Union in Russia and Poland" (the "Bund"), founded in $1897 .^{3}$

During the last two decades of the nineteenth century radical "circles" were founded in a number of cities within the Jewish "Pale of Settlement" (i.e. those provinces of the Russian Empire in which Jews were allowed to reside). 4 The leaders of the "circles" were drawn from that section of the russified Jewish intelligentsia which had fallen under the influence either of the old Populism or the new Marxism. The "circle" members were recruited from the numerous and im-

1 This essay was read, in slightly altered form, at the YIVO Research Conference on Jewish Participation in Movements dedicated to the Cause of Social Progress, New York City, September, 1964.

2 For a discussion of this issue with regard to the Russian situation see Richard Pipes, Social Democracy and the St. Petersburg Labor Movement, I 88 5-1 897 (Cambridge, 1963), and Dietrich Geyer, Lenin in der russischen Sozialdemokratie (Cologne, x962), pp. $80 \mathrm{ff}$. ${ }^{3}$ For general histories of the Russian Jewish socialist movement covering the period under discussion the reader may be referred to M. Rafes, Ocherki po istorii "Bunda" (Moscow, I923); Nahum A. Bukhbinder, Istoriia evreiskago rabochego dvizheniia v Rossii (Leningrad, 1925); Y.Sh.Hertz, and others, ed., Di geshikhte fun Bund, Vol. I (New York, 1962).

4 Broadly speaking, the "Pale of Settlement" included the Ukraine and "New Russia", the White Russian and Lithuanian Provinces, and the ten Provinces which constituted the area formerly known as the Kingdom of Poland. Certain privileged groups of Jews (such as first guild merchants) were allowed to settle outside the Pale, but for the Jewish masses it remained the most obvious mark of Russia's antisemitic policy. 
poverished Jewish proletariat, consisting mostly of artisans employed in small shops under extremely harsh working conditions. ${ }^{1}$

The leaders of these "circles" aimed at creating a worker elite which would stand in the forefront of the Russian revolutionary movement. ${ }^{2}$ The creation of such an elite, they believed, was possible only through an extensive education campaign. The attainment of knowledge would enable the "circle" member to reach the necessary level of "consciousness" (by which was meant an understanding of the forces of nature and society) required of a revolutionary. The "circles" were essentially educational institutions; their leaders were the teachers, and their worker members comprised the student body. They remained peaceful groups, possessing special libraries and offering "courses" on as many as three different levels. The workers would advance from one level to the next as their education progressed. ${ }^{3}$

The first step was to teach the workers Russian, indispensable at a time when relevant literature in Yiddish, their native language, was scant or unavailable. The "circles" also conducted discussions of basic issues, such as wages and hours. ${ }^{4}$ But the concept of knowledge was not restricted to what might be termed practical matters. On the contrary, the leaders determined to enlighten the workers in a wide range of subjects. Thus Leon Bernshtein in Vilna taught his pupils "... how the world was created, the sun and the earth, the seas and the volcanoes ...", as well lecturing on "... the life of peoples, beginning with wild tribes and ending with the English, with their Parliament and trade unions". ${ }^{5}$ In another "circle" among the topics discussed were the emergence of social classes, slavery, serfdom, and capitalism. "Circle" members studied Darwin and Mill, and read the

${ }^{1}$ For an examination of the economic condition of the Russian Jewish proletariat see Sbornik materialov ob ekonomicheskom polozhenii evreev v Rossii (Petersburg, 1904), Vol. I, Part III, Vol. II, Part IV.

2 S. Gozhanskii, "Evreiskoe tabochee dvizhenie nachala 9o-kh godov", in: S. Dimanshtein ed., Revoliutsionnoe dvizhenie sredi evreev (Moscow, 1930), p. 83; T.M.Kopel'zon, "Evreiskoe rabochee dvizhenie kontsa 8o-kh i nachala 9o-kh godov", ibid., p. $7 \mathrm{r}$.

${ }^{3}$ In Homel and Minsk attempts were made to establish legal schools for the workers. See E.A.Gurvich, "Evreiskoe rabochee dvizhenie v Minske $\nabla$ 8o-kh gg.", ibid., p. 37, and Sholem Levin, "Di ershte yorn fun der revolutsie", in: Royte bleter, I (Minsk, 1929), p. 3; for the general characteristics of the circles see also Zhenie Hurvitsh, "Di ershte propagandistishe kraizl", ibid., p. 3 ; Iu. Martov, Zapiski sotsialdemokrata (Berlin, 1922), pp. I 8 ff; I. Gurvich, "Pervye evreiskie rabochie kruzhki", in: Byloe, No. 6 (June 1907), pp. 65-77; Azriel Presman, Der durkhgegangener veg (New York, 1950), pp. 27-28; Avrom Gordon, In friling fun vilner yidisher arbeterbavegung (Vilna, 1926), Pp. I9-2 I.

4 See, for example, "Voprosy (zaniatiia $\mathrm{v}$ vilenskikh s.-d. rabochikh kruzhakh)", in: Sh. Agursky, Di sotsialistishe literatur of yidish in 1875-1897 (Minsk, 1935), pp. 392-391.

${ }^{5}$ Leon Bernshtein, Ershte shprotsungen (Buenos Aires, 1956), p. 64.

B Kopel'zon, op. cit., p. 72. 
masterpieces of Russian literature. ${ }^{1}$ Lev Jogiches, one of the leaders of the Vilna movement, went so far as to bring a skeleton into his "circle" during a lecture on anatomy. ${ }^{2}$

In the light of these examples, to which many more could be added, it is no wonder that the revolutionary aims of the leaders were occasionally obscured by their passion to instruct the workers. Nor is it surprising to find that some "circle" members were more interested in attaining knowledge than in becoming revolutionaries. The "circles" were intended to be schools of socialism, but the workers sometimes regarded them only as schools, placing all their hopes in the power of learning and paying little attention to revolutionary doctrines. This attitude was well expressed by a Vilna worker, who stated in 1892 that "Like a faithful mother knowledge will guide us peacefully over the sea of tears and pain to the land of life." J Jewish artisans thus seized upon the "circle" as an opportunity to learn Russian and to enjoy the forbidden fruits of world culture. As Martov recounts in his memoirs, for some the "circles" were only "... a means of acquiring knowledge and a personal escape from the gloom in which the worker masses subsisted ..."

Inevitably, this attitude led to defections. Some workers left the "circles" to become "externs", in the hope of entering a University. Others left their provincial cities for Petersburg, attracted by the rich cultural life of the capital. ${ }^{5}$ In addition there was a general tendency to ape the intelligentsia, which was revered not for its revolutionary ideals but for its cultural achievements. Some workers came to share the disdain for Yiddish common in intellectual circles, and acquired “... a sort of condescending, contemptuous attitude towards the masses who, one might say, were not considered worthy of socialism's teachings ..."6

In the early I 890's the traditional "propaganda" activities of the "circles" were superseded by a new tactic, known as "agitation".

1 Ibid.; Gordon, op. cit., p. 20; Bernshtein, op. cit., p. 68; Sholem Levin, Untererdishe kemfer (New York, 1946), pp. 104, 107; I. Gurvich, op. cit., p. 72; Martov, op. cit., p. 228.

2 Kopel'zon, op. cit., p. 72.

3 Pervoe maia 1892 goda. Chetyre rechi evreiskikh rabochikh (Geneva, 1893), p. 10.

4 Martor, op. cit., p. 227.

5 Bernshtein, op. cit., pp. 68-69; Kopel'zon, op. cit., p. 78 ; B. Mikhalevitsh, Zikhroynes fun a yidishen sotsialist, I (Warsaw, I92 I), p. 32 ; Martov, op. cit., p. 223. In Minsk some of the "circle" members bought shops and set themselves up as employers. One of the first strikes in the city was directed against one such worker turned employer; see E.A. Gurvich, op. cit., p. 57 .

B Ibid., p. 43. See also the description of Jewish workers who went about “... with a Russian book under their arms and the Russian language on their lips ..." in Mikhalevitsh, op. cit., p. $3^{2}$. 
This entailed a major shift of emphasis within the movement away from study and discussion and towards strikes and demonstrations. The intellectuals, realizing that they were creating a worker elite alienated from the very class they were to lead, turned to the hitherto neglected masses and placed themselves at the head of the struggle to improve the economic conditions of the Jewish proletariat. ${ }^{1}$ As the movement began to broaden its base and assume mass proportions, the "circle" member found his position threatened. Fearing that the switch from peaceful "propaganda" to economic "agitation" would mean an end to the cultural work they prized so highly, the workers were bound to protest.

This protest was first organized in Vilna, where in I 893, after some preliminary literary sallies, a so-called "opposition" group emerged under the leadership of Avrom Gordon. ${ }^{2}$ Gordon, an engraver by profession and a remarkably learned "circle" member, succeeded in gathering around him a sizeable number of workers who rejected the new "agitation" campaign. In his writings Gordon stressed the Lavrovian notion that only through the dissemination of knowledge among the people can progress become a reality. At one time this had been understood by the Vilna intellectuals, who had carried on cultural work in a "holy fire" of enthusiasm. ${ }^{3}$ But the intellectuals had abandonned their historic mission to become labor leaders, to promote strikes which, in Gordon's opinion, had little chance of improving the condition of the Jewish artisans. By forsaking cultural work the intellectuals had revealed themselves as traitors to the movement, and Gordon went on to invoke history (the French Revolution) and Proudhon's teachings in support of his belief that the intelligentsia wishes to delude the people and use them for their own selfish interests: "They [the intellectuals] believe only in their own theories, make the greatest mistakes, drag the blind workers after them, and usually cause the greatest disasters." 4 The "agitation" campaign, in Gordon's

\footnotetext{
${ }_{1}$ Gozhanskii, op. cit., pp. $83 \mathrm{ff}$; Martov, op. cit., pp. $224 \mathrm{ff}$. The two basic texts advocating the new tactic of "agitation" are Arkady Kremer's "Ob agitatsii" (written in 1893 and first published in Geneva in I 897) and S. Gozhanskii's "A briv tsu di agitatorn" (probably written at the end of 1893 ). The latter brochure is published in Historishe shriftn, Vol. III (Paris-Vilna 1939), pp. 626-648.

2 Gordon's writings from this period are collected in his In friling fun vilner yidisher arbeter-bavegung, op. cit. For description of the Vilna "opposition" see Bernshtein, op. cit., pp. I5I-159; P.P. (David Zaslavskii), "Di oppositsie fun 1893 yor", in: Di hofnung, No. I4 (22 Sept.-8 Oct., 1907), p. 4 ; Gozhanskii, op. cit., p. 85 ; Martov, op. cit., pp. $229 \mathrm{ff}$; John Mill, Pioneren un boyer, I (New York, 1946), pp. ror-ros; Hillel Katz Blum, Zikhroynes fun a bundist (New York, 1940), pp. $32 \mathrm{ff}$.

3 Gordon, op. cit., p. 12.

4 Ibid., p. 45.
} 
view, was the intelligentsia's way of preserving a monopoly on that most precious of all commodities, knowledge.

Gordon's views were widely held. In Vilna the "opposition" temporarily split the movement into two hostile camps. ${ }^{1}$ Nor did it die out with the eventual success of the new tactics. As late as igor a Gordon supporter set up a press in his apartment in order to spread the old "opposition" doctrines. "Opposition" groups appeared in other cities, affecting both the Jewish and the Russian movements. In Homel and Brest-Litovsk opposition groups were formed, while in Minsk an "opposition" movement shared some of Gordon's tenets along with its own nationalist deviations. ${ }^{3}$ Two other organizations, though not directly connected with Gordon's "opposition", held strikingly similar views. The "Group of Worker Revolutionaries", active in Bialystok in 1897 , was hostile to the intellectuals and emphasized the importance of spreading knowledge among the workers. ${ }^{4}$ A similar group in Grodno resisted the tactics of economic "agitation" and took a position "against the intellectuals". 5

The "opposition" of the "circle" workers was never a majority movement. The workers clearly needed the intellectuals, and the desperate economic plight of the masses was fertile soil for the new emphasis on trade unionism. But Gordon's ideas never lost their attraction, as one final example will demonstrate. In Minsk, after the mass arrests of 1898 , the movement was forced to make a new start. The leaders, favoring economic agitation, found themselves once again challenged by worker opposition, and in 1899 some workers held a demonstration to protest against the proponents of economic

1 Martov, op. cit., p. 230.

${ }^{2} \mathrm{H}$. Botvinik, "Di vilner may-demonstratsie in I 902 yor", in: Hirsh Lekert, tsum 20-tn yortsayt fun zayn kepung (Moscow, 1922), pp. 26-27.

${ }^{3}$ For Minsk see Levin, Untererdishe kemfer, op. cit., pp. ro2-104, and Khanke Kopelevitsh, "Der onheyb fun kamf", in: Royte bleter, op. cit., p. 4. On Homel see Bukhbinder, "Evreiskoe rabochee dvizhenie v Gomele i 890-1905 gg.", in: Krasnaia letopis', No. 2-3 (1922), p. 42, and for Brest-Litovsk see Mikhalevitsh, op. cit., p. 2 I.

"On the Bialystok "Group" see B. Eidel'man, "K istorii vozniknovedeniia rossiiskoi sots.-dem. partii", in: Proletarskaia revoliutsiia, No. I (1921) p. 35; S. Gel'man, "Pervaia podpol'naia typografiia grupy 'rabochee znamia", in: Katorga i ssylka, No. 6 (27) (1926), p. 46; Mikhalevitsh, op. cit., p. 44; David Gershanovich, "O Moise Vladimiroviche Lur'e", in: K dvadtsatpiatiletiiu pervogo s'ezda partii (I898-1923) (Moscow-Petrograd, 1923), pp. I66-1 74 .

5 The quotation is from P. An-man (Rosenthal), "Der bialystoker period in lebn fun tsentral komitet fun bund (1900-1902)", in: Royter pinkes, I (Warsaw, I921), p. 52. See also A. Lev, "Pervye shagi evreiskago rabochego dvizheniia v g. Grodno", in: Dimanshtein, op. cit., pp. 268-273; V. Akimov-Makhnovets, "Stroiteli budushchago", in: Obrazovanie, No. 4 (1907), p. I I5; "Di arbeterbavegung in Grodno", in: Di letzte pasirungen, No. 14 (25 July, 1905), p. 3 ; Bronislaw Szaszkewicz, “Organizacja grodień'ska P.P.S. w latach i 898-1910", in: Niepodlegtość, Vol. XVI (Sept.-Oct. 1937), pp. 5 I 3 ff. 
action. ${ }^{1}$ The ideas of Gordon's "opposition" - hostility towards the intelligentsia coupled with an emphasis on the importance of cultural work - had taken deep root among a certain section of the Jewish proletariat. They were to exert an influence on the opposition trends of the "agitation" period.

The transition from "circle" propaganda to economic agitation completely altered the character of the Russian Jewish socialist movement. As Gordon had feared, the great emphasis on learning disappeared. Cultural work was not discarded, but it was implemented on a much more practical level. The homely brochures of Gozhansky and the feuilletons in the Yiddish socialist press replaced Darwin and anatomy. ${ }^{2}$ The old "circle" elite was submerged by a new wave of recruits, whose only language was Yiddish and whose level of "consciousness" was very low indeed. The "kasse" or "skhodka" (council) became the organizational backbone of the movement. In the larger cities each trade organized a "skhodka", which in turn elected representatives to an all-trade council (often referred to as the "agitation skhodka"). Committees, consisting of elected and co-opted members, directed the movement on the local level. ${ }^{3}$ These committees eventually merged to form the "General Jewish Labor Union in Russia and Poland" (known as the Bund), which was offically founded in 1897 as a Marxist socialist party representing the interests of the Russian Jewish working class.

Within the movement the "circle" leader was replaced by a new figure, the agitator, whose function was to organize the masses and lead the economic struggle. The intellectuals, concentrated in the local committees and in the higher echelons of the party organization, supervised the movement from above. They helped publish the underground press, printed proclamations, maintained contact with other cities, and planned political demonstrations. They did not usually take a direct part in economic agitation, remaining somewhat aloof from the worker masses and, for conspiratorial reasons, even unknown to them. ${ }^{4}$

' Bukhbinder, "Evreiskoe rabochee dvizhenie v Minske", in: Krasnaia letopis', No. S (1923), p. I3I.

2 For a list of Gozhanskii's popular brochures see Hertz, op. cit., p. 98. Feuilletons touching on various aspects of worker life appeared in the local Bundist press.

3 This was the basic organizational pattern, though certain differences did exist from city to city. See G. Aronson, "Tsu der geshikhte fun der sotsialistisher un arbeter bavegung", in Vitebsk amol (New York, 1956), p. 302; Vladimir Medem, Fun mayn leben, I (New York, I923), pp. I99ff (Minsk); An-man, op. cit., pp. $46 \mathrm{ff}$ (Bialystok); "Di arbeterbavegung in Grodno", op. cit,; "Ustav rabochei organizatsii", in: Rafes, op. cit., pp. 3 1 5-326 (Vilna); "Konstruktsiia partiinoi organizatsii "bunda", ibid., pp. 326-328 (Kovno); "Gomel'skoe rabochee dvizhenie", in: Agursky, op. cit., p. 360.

4 See, for example, An-man, op. cit., p. 47, and Medem, op. cit., p. 200. R. Abramovitch 
The early years of the "agitation" period were characterized above all by the strike movement. A wave of strikes transformed the "Pale of Settlement" into a battleground between attacking workers and besieged employers. "Strikism" became the order of the day, and the slogan "a twelve hour day, from seven to seven" became the rallying cry of the movement. ${ }^{1}$

Under these radically changed conditions new trends of worker opposition arose. One such trend involved opposition to the intellectuals' position on the issue of terror. The economic struggle of the Jewish proletariat was marked by terrorist activities of all kinds; attacks on employers, strike breakers, and informers were common occurences. Thus in Dvinsk some clerks advised their employers that, unless their conditions were improved, "... we shall be forced to begin with your windows and end with your heads."' In the early days of the Bialystok labor movement the workers "... cracked the skulls of the factory owners [and] broke the looms ..."3 Terrorist acts were carried out largely by new recruits to the movement, workers who had never attended the "circles" and who had little regard for party discipline." Their actions were fostered by the Russian revolutionary tradition; in some instances, the martyrs of the "People's Will" became heroes for the Jewish workers. ${ }^{5}$

The socialist leadership, opposed to terror on principle but ambivalent in practice, did its best to combat this unwelcome trend. Antiterror articles appeared in the party press. The Bund condemned terror because it "... obscures the social-democratic consciousness of the workers, worsens their material situation and discredits the labor movement." Workers were informed that terrorism was "shameful"7

comments in his memoirs that "None of the workers ... know our [the intellectuals] real names and addresses." R. Abramovitch, In tsvey revolutsies, Vol. I (New York, 1944), p. 64 .

1 For a statistical study of the Jewish strike movement see Ber Borochov, "Tenuat hapoalim ha-yehudit be-misparim", in: L. Levita, and D. Ben-Nahum, eds., Borochov, Ketavim, Vol. II (Tel-Aviv, 1958), pp. 260-320.

2 Poslednaia izvestiia, No. 91 (25 Oct. 1902).

3 Der bialystoker arbeter, No. I (April, I 899), p. is. For other examples see Arbeter bletel (Minsk), No. 8 (Aug. I 897), in: Historishe shriftn, op. cit., p. 743; Levin, "Di ershte yorn fun revolutsie", op. cit., p. 5; M. Daitch, "Vegn mayn revolutsionerer arbet", in: Royte bleter, op. cit., p. 3 ; "Unzer arbet in berditsheverzhitomirer svive rayon", in: Di arbeter shtime, No. 37 (June, I904), p. I5; "Der mord fun a loynketnik in Bialystok", in: Der idisher arbeter, No. 7 (August, I 899), pp. I9-20.

4 Rafes, "Girsh Lekert i ego pokushenie", in: Krasnyi arkhiv, II (XV) (1926), p. 89.

5 In the feuilliton "A brief tsu Berel'n", in: Der bund, No. I (Jan., I904), the main character is very fond of the old terrorist heroes: "Each was engraved in his heart, each did he invest with the highest qualities..."

- Der idisher atbeter, No. I 2 (I90r), p. 98.

7 Minsker flug-bletel, No. 5 (March, I902). 
and that "... one must talk with the strike breakers, one must make them understand, for they act from ignorance."1

How effective these admonitions were is debatable. What is evident is that the masses were dissatisfied with the leadership's attitude, and that this dissatisfaction occasionally expressed itself in organized opposition. In Vilna, for example, special groups of "boeviks" (fighters) were formed to carry out terrorist acts. ${ }^{2}$ It was from this background that Hirsh Lekertemerged to make his assassination attempt on the Governor of Vilna in I902. Lekert, a young shoemaker, was executed by the Czarist government, thus becoming the first great martyr of the Russian Jewish labor movement.

The Lekert affair revealed the extent to which pro-terrorist sentiments had permeated the movement. The Vilna committee had split over the proposed assassination, while the fifth conference of the Bund, meeting shortly after Lekert's execution, adopted a resolution favoring "organized vengeance" as an acceptable socialist tactic. ${ }^{3}$ This resolution was immediately attacked by the Foreign Committee of the Bund, and was rescinded at the Bund's fifth congress. ${ }^{4}$

Lekert's deed also exacerbated the conflict between workers and intellectuals over the issue of terror. In Vilna the intellectuals of the committee were charged with responsibility in the shoemaker's execution, as they had failed to lend complete support to his plan. ${ }^{5}$ In 1903 a special terrorist group, comprised of former Bundists, was formed in Riga. ${ }^{6}$ In Grodno a group of strikers at Shereshevsky's factory left the movement after a dispute over terror, ${ }^{7}$ while in Lodz some sixty workers left the Bund for the same reason, only to return

1 "Vos darfen mir ton gegen shtraykbrekher?", in: Der freyheytsglok, No. 2 (April, 1902), p. 9. See also "Di arbeter bavegung un der terror", in: Di arbeter shtime, No. 14 (1899), pP. I-4; "Vegen bruns shrayk", in: Der klasen-kamf, No. 4 (April, 190I), p. 2; "Unzer Io-ter tsuzammenfor", in: Der veker, No. 8-9 (March, I902), p. 2.

2 Y.A. Khatovitsh, "Dos vos ikh veys vegn Hirsh Lekert", in: Hirsh Lekert ..., op. cit., p. 13.

3 See the accounts in Isak Mitskin, "Di vilner organizatsie fun bund un Lekerts atentat", ibid., pp. 42-46; Bentse Levin, "Di 5-te konferents fun "bund', zikhroynes", ibid., pp. 58-60; Hertz, Hirsh Lekert (New York, 1952), pp. 43 ff. The text of the resolution on "organized vengeance" is published in Hertz, Di geshikhte ..., op. cit., pp. $245-246$.

4 See Medem, op. cit., pp. 3 I 5 ff. For the Foreign Committee's point of view see the brochure $\mathrm{K}$ voprosu o tertorisme (London, I903). The resolution of the Bund's fifth congress is published in V-yi s'ezd vseobshchago evreiskago rabochago souiza $\mathrm{v}$ Litve $\mathrm{i}$ Pol'she i Rossii (London, I903), pp. 29-30.

5 Botvinik, op. cit., p. 45.

B Its program ("Programma rizhskoi sotsial-demokraticheskoi boevoi organizatsii") is published in Bukhbinder, Istoriia ..., op. cit., pp. 262-264.

7 Der bund, No. 3 (April, 1904), p. 9. 
with the acceptance of the principle of "organized vengeance". ${ }^{1}$ In Bialystok, those workers who demanded action against police repressions swelled the ranks of the anarchist group "Bor'ba"(Struggle), which attained considerable strength in the city. ${ }^{2}$

If the unlettered masses expressed their dissatisfaction with the leadership's attitude towards terror, the more advanced workers accused the intellectuals of running the movement in an undemocratic and monopolistic manner. In Dvinsk, for example, the workers succeeded in gaining complete control over the city movement and excluded all intellectuals from the local committee. ${ }^{3}$ In Homel the workers, annoyed by the extreme conspiratorial nature of the organization, called for more democracy. The leaders replied with an irate proclamation, advising the workers "... not to play with the word "democrat"."4

Tendencies towards centralization and a greater emphasis on political control over the labor movement, emphasized by the resolution on organization at the Bund's fifth conference, ${ }^{5}$ confirmed the fears of some workers that the movement was being taken out of their hands. The implementation of the new program, which was interpreted as an attack on the democratic principle within the movement, provoked worker opposition in various cities. ${ }^{6}$ A year later a new "opposition" group, founded in Minsk, demanded that the movement be led only by workers; the group seceded from the Bund and formed its own "Workers' Organization".7

The most significant opposition movement, however, derived from the all-important issue of economic versus political action. The early years of the "agitation" period were characterized by a trade union orientation, and the workers attracted to the movement were motivat-

1 Volf A. Yasni, Geshikhte fun der yidisher arbeter bavegung in Lodz (Lodz, 1937), pp. 2I4-2I 5 .

2 Benjamin Shtufler, "Tsvey pioneren fun der revolutsionerer arbeter-bavegung in Bialystok", in: H. Frank, and others, eds., Natsionale un politishe bavegungen ba yidn in Bialystok, I (New York, 195 I), p. 53. See also Belostokhanin, "Iz istorii anarkhicheskago dvizheniia v Belostoke", in: Almanakh, Sbornik po istorii anarkhicheskago dvizheniia v Rossii, I (Paris, 1909), pp. 5-28.

${ }^{3}$ A.M. Ginsburg, (Naumov), "Nachalnie shagi vitebskogo rabochego dvizheniia", in: Dimanshtein, op. cit., p. I I 2.

4 "O konspiratsie" ( 1902 ), published in Bukhbinder, "Evreiskoe rabochee dvizhenie v Gomele", op. cit., pp. 80-8I.

5 See Rafes, Ocherki ..., op. cit., pp. 80-8x, for the text.

${ }^{6}$ Hertz, Di geshikhte fun bund in Lodz (New York, 1958), p. 78. An account of the changes wrought by the new organizational tactics on the local level (in this case in Grodno) is given in Akimov-Makhnovets, op. cit., p. IIs.

7 Bukhbinder, "Evreiskoe rabochee dvizhenie v Minske", op. cit., pp. I44-I 45. 
ed above all by a desire to improve their economic conditions. The leaders hoped to guide them from an awareness of their economic needs to an awareness of the political situation, from strikes to political activities. They never tired of pointing out that only through basic social and political change could the lot of the masses be really improved; their slogan was "through economics to politics". ${ }^{1}$ This task was naturally made easier by the Czarist police, who brought home to the workers as the intellectuals never could the close connection between economic and political struggle in Russia. Nonetheless, the workers frequently concerned themselves only with the economic aspect of the movement. Many remained indifferent or even hostile to politics, and to the leaders who urged political action.

This indifference is much in evidence in the early days of the Jewish labor movement. In some cities the movement originated on a legal basis, with the workers attempting to gain their economic demands without antagonizing the authorities. The most obvious example was the widespread use of Catherine II's longforgotten law restricting the artisan's working day to twelve hours. The existence of this law was brought to the attention of the Vilna socialist intelligentsia, who used it in the early I 890's as a means to convince the workers to strike for a twelve hour day. ${ }^{2}$ The success of this tactic was immediate, and as late as 1897 the Vilna proletariat was still being urged to base their demands on the old statute. ${ }^{3}$ Significantly, it was also utilized in Mohilev (1903), Minsk (1894), Brest-Litovsk (the middle I 890's), and Bialystok (r 894). ${ }^{4}$

Other tactics were also employed by workers seeking to operate within the narrow framework of Czarist legality. In Minsk and Homel petitions were sent to the authorities requesting an amelioration of working conditions. ${ }^{5}$ In 1892 a Vilna worker, in a remarkable petition, begged the Governor of Vilna to intercede on behalf of the oppressed worker masses: "We turn therefore to Your Excellency with a humble

\footnotetext{
1 An alter bekanter (Pesakhson), "Der onheyb fun der yidisher arbeter-bavegung in Lodz", in: Royter pinkes, Vol. II (Warsaw, 1924), p. I6r. For a typical example of this tactic see the proclamation "Ko vsem grodneskim rabochim i rabotnitsam", published in Dimanshtein, op. cit., pp. 278-279. The proclamation attacks, in turn, the employer, the police, and the factory inspector, leading up to an attack on the autocracy.

2 Gozhanskii, op. cit., pp. 86-87; Martov, op. cit., pp. 193-194; Mill, op. cit., p. 86.

3 Tsu alle vilna'r arbeter un arbeterinen (Nov, I 897).

4 Ko vsem rabochim i rabotnitsam (Mohilev, I903); Levin, Untererdishe kemfer, op. cit., pp. 97-98 (Minsk); Mikhalevitsh, op. cit., p. 22 (Brest-Litovsk); Der idisher arbeter, No. 4-5 (Nov., 1897), pp. 26-27 (Bialystok).

5 See Tsh., "Di lage fun di minsker handl-ongeshtelte in di 8o-ker yorn", in: Tsaytshrift, IV (Minsk, I930), pp. 133-135; "Gomel'skoe rabochee dvizhenie", op. cit., pp. 362-361. The dates of the petitions are 1889 (Minsk) and 1894 (Homel).
} 
plea for help. It is only within the power of Your Excellency to restrain the inhuman excesses of the employer. The improvement of our hard and unfortunate situation lies in your hands alone."1

In order to avoid the prohibition on strikes, which in Russia was based on the breach of contract principle, workers would strike at the beginning of their term of employment. Thus the bristle makers “... always wanted legal strikes. Usually we struck at the beginning of a 'zman' (i.e. term of employment), we sought out legal forms in order to appear right to the police ..."2 Workers in Kishinev announced their strikes two weeks in advance, this being the minimum amount of time required to advise the employer of one's intention to leave work. ${ }^{3}$

The workers also appealed to factory inspectors for aid against their employers. The Bundist leadership waged a long campaign against this practice, proof of the workers' stubborn belief that the inspectors were really on their side. ${ }^{4}$ In Krinki the inspectors were referred to as "fathers" until, in the words of a Bundist proclamation, the workers discovered that "... he is not their father and they are not his children." But despite frequent warnings workers continued to look to the inspector as their ally, and in fact the latter did occasionally side with them during labor disputes. ${ }^{6}$

Usually the legal tactics of the workers failed. Petitions to Governors and appeals to factory inspectors went unanswered, forcing the workers to resort to illegal strikes. There remained, however, a definite hostility to political involvement among a certain section of the proletariat. The "indescribable fear of "politics" ascribed by Pesakhson to the Lodz working class may be exaggerated, ${ }^{7}$ but there are indications of a hard core resistance to the political orientation of the movement. In 1900 a Bundist proclamation to the Bialystok clerks created a disturbance for the simple reason that, at the end of the proclamation, socialism was

1 The petition, originally written in Russian, is published in Yiddish in Yefim Yeshurin, ed., Vilne, a zamlbukh gevidmet der shtot Vilne (New York, 1935), pp. 133-134.

${ }^{2}$ Der veker, No. 5 (May, I900), p. 6. See also Listok'rabotnika', No. 6 (Feb. 1898), p. I8, for the use of this tactic in Bialystok.

3 Poslednaia izvestiia, No. 83 (28 Aug., 1902).

4 See, for example, Tsu alle bialystoker arbeter un arbeterinen (Nov., 1903); Der idisher arbeter, No. I (1898), p. 46; "Fabriksinspektsion", in: Der varshaver arbeter, No. 5 (Aug., 1900), pp. 1-5.

5 Di arbeter shtime, No. 4-5 (Sept., I 897), pp. I I, 14.

- "Materialy dlia kharakteristiki rabochego dvizheniia nashego goroda Vilny za poslednic 4-5 let (sobrany v I 895 g.)", in: Agursky, op. cit., p. 416; Di arbeter shtime, No. 22 (March, I901), p. 8; Listok "rabotnika", No. 2 (Dec., I892), p. 3 ; Rabotnik, No. 3 \& 4 ( 1897 ), p. 9r. According to this last source, during a strike in Vilkovishki the inspector "Officially ... warned the workers on breaking their terms, but in a private letter to the factory owner he persuaded him to satisfy the just demands of the workers."

7 Pesakhson, op. cit., p. I6I. 
mentioned. The workers in the "skhodkes" claimed that this would frighten away the masses, and that the proclamation should discuss only the economic needs of the workers. ${ }^{1}$ In Warsaw some workers actually accused the Bundist leaders of having caused police repressions. According to the local Bundist paper they insisted that "... workers should not be involved in politics." In Vilna some workers refused to join May Day demonstrations. Instead they demanded "purely worker holidays" and would have nothing to do with political action. ${ }^{3}$

These last two incidents took place in I 901 and I 903 , and the workers were probably under the influence of the Zubatov doctrine of legalism then permeating the "Pale of Settlement". Zubatov, the originator of Russian police socialism, had succeeded in making certain inroads in the Moscow labor movement; he had hopes of duplicating this achievement among Jewish workers, hopes which were partly realized during the years $1901-1903.4$

Zubatovism, as presented to the Jewish workers, was based on the notion that workers, like everyone else, are motivated entirely by enlightened self-interest. Their only aim is to better their material and cultural conditions. If the workers are allowed to pursue these aims in peace, they will remain indifferent to politics. It follows that the proletariat cannot profit from an alliance with the intelligentsia, whose own interests are quite different. The intelligentsia wishes to divert the workers into a senseless political struggle which can only harm their just demands for economic and cultural improvement, improvement which can be realized only if the workers abandon illegality and ally themselves with the government. The workers should found unions, operated on democratic principles without the interference of the intelligentsia. The government would support their struggle for a decent wage and shorter hours. ${ }^{5}$

Such an argument had an obvious appeal to the Jewish workers. The Zubatov doctrine could attract both the proponents of the old "opposition" and those who had participated in the various opposition trends (excluding that of terrorism) of the "agitation" period. On the one hand it held out the possibility of peaceful, cultural activity. On the

1 An-man, op. cit., p. 65.

2 "Vi kumt an arbeter tsu politik", in: Der varshaver arbeter, No. 7-8 (May, I90I), p. I.

3 Poslednaia izvestiia, No. 135 (9 July, 1903).

4 On the Zubatov movement see S. Ainzaft, Zubatovshchina i Gaponovshchina (Moscow, 1925).

5 The above account is based on a typescript of a lecture read in the Zubatov "fereins" (unions) in Minsk. The typescript, signed "Gruppa soznatel'nykh rabochikh", is available in the Bund Archives, New York City. See also Zubatov's comments in D. Zaslavskii, "Zubatov i Mania Vilbushevits", in: Byloe, No. 3 (31) (March, 1918), pp. I Ioff. 
other, it denounced political action, championed legalism, and appealed directly to the economic interests of the masses. In addition, it was strongly opposed to the intellectuals' imposing their views on the labor movement, though it saved for them the role of cultural advisors. As for the idea of a labor movement allied with the authorities, if the workers had been prepared to cooperate with Governors and inspectors they would not object to cooperation with the police. As a worker in Minsk commented, "If one may appeal to a factory inspector, why should this be forbidden with regard to gendarme officers?"1

Zubatovism's appeal to the traditional discontents within the Jewish labor movement was enhanced by developments around the turn of the century. There were growing difficulties with the strike movement; strikes were now being held not to win new victories, but to stave off fresh defeats. At the same time the Bund was attempting to centralize the movement and place it under firm political control. Just as the transition from "propaganda" in the "circles" to "agitation" resulted in the "opposition" of the early I 890 's, so the transformation of a trade union oriented movement into a centralized organization stressing political action paved the way for the founding of the "Independent Jewish Labor Party" in Minsk in 190r."

The actual inroads made by Zubatovism are difficult to measure, but it is clear that many important centers were affected by its propaganda. The Homel Bundist journal noted that Zubatov had attracted some "stupid workers who believe the dog". ${ }^{3}$ Such workers existed in many cities. In Vitebsk, for example, the leaders of the locksmiths' organization refused to join a May Day demonstration in 1904: “And

1 Mikhalevitsh, op. cit., Vol. II (Warsaw, I9I2), p. 14. It should be pointed out that Zubatovism in Minsk attracted not only workers but socialist intellectuals as well. To these intellectuals it held out the enticing prospect of participating in a mass legal movement dedicated to the economic and cultural welfare of the working class. The defection of some Bundist intellectuals to the "Independent" camp has been stressed by S.M. Shvarts in his controversy with Ia.Sh. Gerts concerning the relationship between the Bund and the "Independents". See S. M. Shvarts, Menshevizm i bol'shevizm v ikh otnoshenii k massovomu rabochemu dvizhenii (New York, no date), pp. I $26 \mathrm{ff}$., and Ia.Sh. Gerts, and S.M. Shvarts, Zubatovshchina v Minske (New York, I962), especially Shvarts, "Otvet Gertsu", pp. 6ff. Whatever the exact nature of this relationship, it is clear that the doctrine of legalism, by reserving a place for disaffected Bundist intellectuals, succeeded in transcending the limitations of a purely worker protest movement and came to offer a viable alternative to "Bundism".

2 B. Frumkin, "Zubatovshchina i evreiskoe rabochee dvizhenie", in: Perezhitoe, III (I9I I), pp. 21 2-2I3; "Novoe o Zubatovshchine", in: Krasnyi arkhiv, I ( I 222), pp. 327-328 ; Zaslavskii, "Zubatov ...", op. cit., pp. rooff. The Manifesto of the "Independents" is published in Bukhbinder, "Nezavisimaia evreiskaia rabochaia partiia", in: Krasnaia letopis', No. 2-3 (1922), pp. 222-223.

3 Der kamf, No. I (Sept., i90o), p. I6. 
when hundreds of non-organized workers, together with class conscious workers of Vitebsk celebrated the sacred workers' holiday, when they thus demonstrated their solidarity, their unity with the workers of the entire world, the organized 'class conscious' locksmiths worked, to the joy of their employers and the gendarmes."1

It was in Minsk, however, that the movement really took root, thanks in part to the support of the gendarme chief Vasiliev. Here the "Independent Jewish Labor Party", armed with its slogan "bread and knowledge", succeeded in attracting a mass worker following. "Fereins" (unions) were established in the trades and carried on a carefully planned economic struggle with the support of the police. Employers, knowing of the connections between the police and the workers, were forced to make concessions. "Strikism" became a popular worker sport. ${ }^{2}$

The "Independents" paid special attention to cultural work. Lectures and courses were arranged by a "cultural commission". Each "ferein" possessed a library and carried on cultural work among its members. The painters' "ferein", for example, announced that it would concentrate on raising "the cultural level of our trade". 3 The "Protocol book" of the carpenters" "ferein"4 reveals a similar emphasis on cultural activity. The intellectuals within the movement were assigned the role of spiritual mentors; the economic struggle was left in the hands of the workers themselves. ${ }^{5}$

The "Independents", with their unique appeal to the Jewish workers and their success in gaining intellectual support, were easily the most important of the opposition factions under consideration. Gordon's "opposition" and similar groups of the r890's had lacked a real popular base, while the opposition trends of the post-Bund period only occasionally attained organizational form. The "Independents", on the other hand, were able to engage in economic and cultural work on a mass scale. Yet they too were soon obliged to curtail their

1 Der bund, No. 2 (March, 1904), pp. 8-9. For evidence of Zubatov's influence elsewhere see ibid., (Mohilev); An-man, op. cit., pp. 5 I- 22 (Bialystok and Grodno); Mikhalevitsh, op. cit., II, p. 9 (among bristle makers); Bukhbinder, "O zubatovshchine", in: Krasnaia letopis', IV (I922), p. 319 (Bobruisk).

2 Bukhbinder, "Nezavisimaia ...", op. cit., p. 212.

3 Arbets-mark, No. 8 (Feb., I903). See also Bukhbinder, "O zubatovshchine", op. cit., p. 327 ; Bukhbinder, "Nezavisimaia ...", op. cit., p. 258 ; B. Frumkin, op. cit., pp. 222-223.

4 Protokol-bukh fun ferein fun di stoliers, Minsk, Dets. 1902-2 Yuli I903, available in the Bund Archives. See the minutes of 30 Dec., 1902, 13 Jan., 1903.

5 "Novoe o zubatovshchine", op. cit., pp. 317-318; "Minskim rabochim i rabotnitsam" (Aug., I90I), published in Bukhbinder, "Nezavisimaia ...", op. cit., p. 247. The Manifesto of the "Independents" announced that the Party would be run on a democratic basis. See ibid., p. 243. 
activities, though their influence lingered on. In 1903, owing to a variety of reasons - among them the strength of the Bund, the failure of the Czarist regime to support police socialism, and the Kishinev pogrom - the "Independents" were forced to disband. ${ }^{1}$

One reason for the general failure of opposition groups in the Russian Jewish socialist movement was the nature of the regime; revolutionary or labor organizations, even if they were semi-legal (as were the "Independents"), were extremely difficult to maintain for any extended period of time. Another reason was the authority and popularity of the Bund among the Jewish masses. In the last analysis, worker opposition posed a serious threat only at those times when the socialist movement was undergoing organizational and tactical changes. Otherwise it remained only an irritant, albeit a persistant one, to the leadership of the Russian Jewish socialist movement.

\footnotetext{
${ }_{1}$ See Tsu alle yidishe arbeter un arbeterinen (July, 1903), announcing the Party's intention to end its existence. This followed a similar proclamation, Tsu unzere parteygenossen (Feb., 1903), which noted the failure of the "Independents" to take root in Vilna, a failure caused largely by the strength of the Bund in that city.
} 